In this issue:

ACRL Officers for $1975 / 76$

Inside Washington

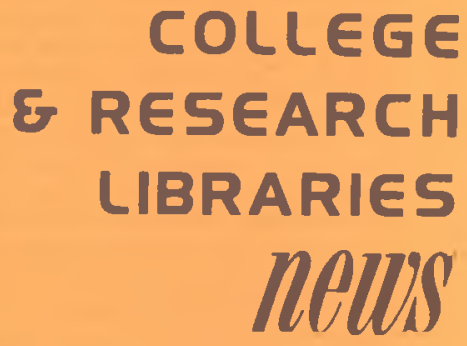

Report on ACRL Preconference

News From the Field

Report on Peter Drucker's Speech at ACRL Membership Meeting

Highlights of the ACRL Board of Directors Meetings in San Francisco

People

Classified Advertising

\title{
ACRL Officers for 1975/76
}

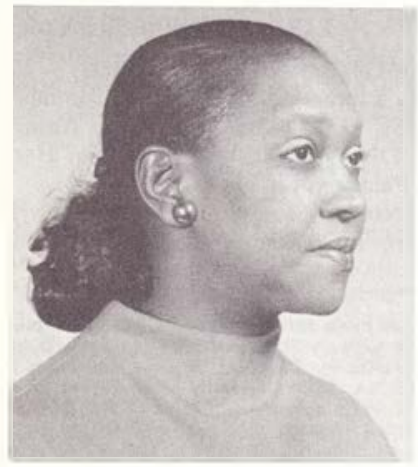

Louise Giles

Louise Giles, dean of learning resources at Macomb County Community College, Warren, Michigan, will serve as president of the Association of College and Research Libraries for 1975/76. As president of ACRL, Giles chairs the ACRL Executive Committee, the ACRL Board of Directors, and the ACRL Conference Program Planning Committee for the 1976 Annual Conference in Chicago. She also serves as a member of the Choice Editorial Board and as an ex-officio member of the ACRL Planning Committee and of all units of ACRL. As president of the division, Giles represents ACRL and ALA to other educational and professional organizations.

Giles' previous service to ACRL and ALA includes representing ACRL on the Joint Com-

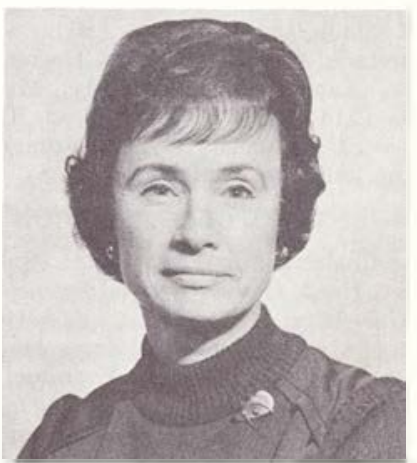

Connie R. Dunlap

mittee on Two-Year College Learning Resources Programs (AACJC/AECT/ACRLALA), membership on the ALA Audiovisual Committee, the ACRL Board of Directors, the Conference Program Planning Committee for the 1974 Annual Conference in New York. In 1973/74 she chaired the Community and Junior College Libraries Section of ACRL. In 1974/ 75 she chaired the ACRL Planning Committee. She has been a member of ALA Council since 1972.

Connie R. Dunlap, university librarian at Duke, is the newly elected vice-president and president-elect of ACRL. In the recent election Dunlap received 1,398 votes. Joanne Harrar, director of libraries, University of Maryland at College Park, received 1,221. 
Dunlap is a member of ALA Council, chaired the Clarence Day Award Jury in 1974/75, and has served as chairman of the Acquisitions Section, Resources and Technical Services Division, the Organization Committee of RTSD, and in 1972/73 was president of RTSD.

As vice-president of ACRL, Dunlap will serve as a member of the ACRL Executive Committee and ACRL's Board of Directors. She will chair the ACRL Planning Committee and the ACRL Conference Program Planning Committee for the 1977 Annual Conference in Detroit. At the close of the 1976 Annual Conference in Chicago, Dunlap will become ACRL's thirty-eighth president.

The results of the ACRL section elections follow. For each position, the elected candidate is listed first. The number of votes earned by each candidate is listed in parentheses.

\section{AGRICULTURE AND BIOLOGICAL SCIENCES SECTION}

Vice-Chairman/Chairman-Elect: Barbara B. Gordon, Forest Resources Librarian, University of Washington, Seattle, Washington (114); Elisabeth B. Davis, Biology Librarian, University of Illinois, Urbana, Illinois (85).

Secretary: Ame H. Richards, Documents Librarian, Kansas State University, Manhattan, Kansas (114); Eris E. Roth, Head, Technical Services, U.S. Social Security Administration Library, Baltimore, Maryland (82).

\section{ANTHROPOLOGY SECTION}

Vice-Chairman/Chairman-Elect: Robert E, Pfeiffer, Head, Graduate Social Science Libraries, University of California, Berkeley, California (84); Thein Swe, Bibliographer, Northwestern University Library, Evanston, Illinois (65).

Secretary: Suzy M. Slavin, Assistant Head, Reference Department, McGill University Library, Montreal, Quebec, Canada (80); Patrick Ashley, Head, Search Department, Northwestern University Library, Evanston, Illinois (69).

Member-at-Large: David L. Perkins, Head Bibliographer, California State University, Northridge, California (81); Patricia Ann White, Reference Librarian, Michigan State University, East Lansing, Michigan (69).

\section{ART SECTION}

Vice-Chairman/Chairman-Elect: Mary Ashe, Art and Music Librarian, San Francisco Public Library, San Francisco, California (148); Rosella L. Ferster, Art Cataloger, Duke University Library, Durham, North Carolina (69).

Secretary: Barbara E. Reed, Assistant Art Librarian, State University of New York at Buffalo, Buffalo, New York (128); Stephanie J. Frontz, Art Librarian, University of Rochester, Rochester, New York (89).

\section{ASIAN AND AFRICAN SECTION}

Vice-Chairman/Chairman-Elect: Charles R. Bryant, Curator, Southeast Asia Collection, Yale University Library, New Haven, Connecticut (87); John A. Eilts, Near East Bibliographer, University of Michigan Library, Ann Arbor, Michigan (62).

Member-at-Large: Karl K. Lo, Head Librarian, Asiatic Collection, University of Washington, Seattle, Washington (84); Jack A. Siggins, Director, East Asia Collection, University of Maryland, College Park, Maryland (66).

\section{COLLEGE LIBRARIES SECTION}

Vice-Chairman/Chairman-Elect: Marjorie $H$. Sibley, Head Librarian, Augsburg College, Minneapolis, Minnesota (405); Melvin R. George, Director of the Library, Northeastern Illinois University, Chicago, Illinois (357).

Secretary: Edmund R. Arnold, Director of Library Services, Cornell College, Mount Vernon, Iowa (482); James F. Parks, Jr., Head Librarian, Millsaps College, Jackson, Mississippi (269).

\section{COMMUNITY AND JUNIOR COLLEGE LIBRARIES SECTION}

Vice-Chairman/Chairman-Elect: Jo Ellen Flagg, Librarian, Forest Park Community College, St. Louis, Missouri (202); Ambrose Easterly, Director of Library Services, Harper College, Palatine, Illinois (136).

Secretary: Stanley N. Ruckman, Head Librarian, Linn-Benton Community College, Al-

News items for inclusion in C\&RL News should be sent to Mary Frances Collins, Assistant Director of Libraries for Technical Services, University Library ULB-35A, State University of New York at Albany, 1400 Washington Are. Albany, NY 12222. Advertising (including classified ads) should be sent to Leona Swiech, Advertising Office. American Li brary Association, 50 E. Huron St., Chicago, IL 60611 . Production and circulation matters are handled by ALA Central Production Unit, at the above address.

News edifor: Mary Frances Collins, Assistant Director of Libraries for Technical Services, State University of New York at Albany, Albany. Associate News editor: Anne Dowling. Assistant Librarian, Acquisitions Department, Library, State University of New York at Albany. Editor: Richard D. Johnson, Milne Library, State University College, Oneonfa New York 13820. President. ACRL: Louise Giles. Executive Secretary, ACRL: Beverly P. Lynch.

College Research Libraries is published by the Association of College and Research Libraries, a divișion of the American Library Association, 17 times yearly-6 bimonthly journal issues and II monthly (combining July-August) News issues-at |20|-05 Blulf St., Fulton, MO 6525I. Subscription, $\$ 15.00$ a year, or to members of the division, $\$ 7.50$, included in dues. Second-class postage paid at Fulton, Missouri $6525 \mathrm{~L}$.

(C) American Library Association 1975. All material in this journal subject to coprright by the American Library Association may be photocopied for the noncommercial purpose of scientific or educational advancement. 
bany, Oregon (172); Robert F. Schremser, Librarian, Alexander City State Junior College, Alexander City, Alabama (161).

\section{EDUCATION AND BEHAVIORAL SCIENCES SECTION}

Vice-Chairman/Chairman-Elect: Ruth Bauner, Education/Psychology Librarian, Southern Illinois University, Carbondale, Illinois (171); Margaret Perry, Head Librarian, Education Library, University of Rochester, Rochester, New York (156).

Secretary: Eva L. Kiewitt, Librarian, Graduate Library School, Indiana University, Bloomington, Indiana (227); Robert Baumruk, Chief, Social Sciences and Business Department, Chicago Public Library, Chicago, Illinois (100),

\section{LAW AND POLITICAL SCIENCE SECTION}

Vice-Chairman/Chairman-Elect: Catherine A. Porter, Librarian, Vinson, Elkins, Searls, Connally \& Smith (Attorneys at Law), Houston, Texas (168); Oleg Kudryk, Head, Acquisitions Department, Indiana University Libraries, Bloomington, Indiana (81).

Member-at-Large: Signe Larson, Head, Research Services, U.S. Department of the Interior Library, Washington, D.C. (226).

\section{RARE BOOKS AND MANUSCRIPTS SECTION}

Vice-Chairman/Chairman-Elect: J. William Matheson, Chief Librarian, Rare Book Division, Library of Congress, Washington, D.C. (271); Clyde C. Walton, Director of Libraries, Northern Illinois University, De Kalb, Illinois (160).

Secretary: N. Frederick Nash, Rare Book Room Librarian, University of Illinois, Urbana, Illinois (273); Shirley B. Lebo, Principal Evaluations Officer, Library of Congress, Washington, D.C. (150).

Member-at-Large: Vesta Lee Gordon, Assistant Curator for Technical Services, Manuscripts Department, Alderman Library, University of Virginia, Charlottesville, Virginia (218); J. Richard Phillips, Special Collections Librarian, Amherst College, Amherst, Massachusetts (200).

\section{SLAVIC AND EAST EUROPEAN SECTION}

Vice-Chairman/Chairman-Elect: George C. Jerkovich, Head, Slavic Department, University of Kansas Libraries, Lawrence, Kansas (66); Oleg Kudryk, Head, Acquisitions Department, Indiana University Libraries, Bloomington, Indiana (54).

Secretary: Benedict Markowski, Burton Historical Collection, Detroit Public Library, De- troit, Michigan (71); Christopher J. Guleff, Media Librarian, Community College of Denver, Auraria Campus, Denver, Colorado (46).

Member-at-Large: Eryk Talat-Kielpsz, Senior Slavic Cataloger, Ohio State University Library, Columbus, Ohio (62); Gordana Rezab, Assistant Acquisitions Librarian, Western Illinois University, Macomb, Illinois (55).

\section{UNIVERSITY LIBRARIES SECTION}

Vice-Chairman/Chairman-Elect: C. James Schmidt, Director of Libraries, State University of New York at Albany, Albany, New York (887); James K. Zink, Director of Libraries, University of Oklahoma, Norman, Oklahoma (553).

\section{Drexel Library School Is OCLC Affiliate}

The Drexel University Graduate School of Library Science has become the first library school to be an educational affiliate of the Ohio College Library Center (OCLC), Dean Guy Garrison has announced.

The Graduate School of Library Science will use the system totally for educational purposes, by special arrangement with the OCLC Board of Directors. Access to the data base will allow students to have direct hands-on experience in the classroom with one of the major technological innovations in the library field today.

Use of OCLC will supplement other on-line computer services already available through the school's information science laboratory, which presently provides access to bibliographic data bases through the System Development Corporation and the Lockheed Missiles and Space Co. The school also has on-line access to general-purpose computational facilities through the UNICOLL Corporation, a subsidiary of the University City Science Center, a regional consortium of educational and research institutions in the Philadelphia area.

Becoming an educational affiliate of OCLC is one more step in the expansion of the laboratory resources of the Graduate School of Library Science to accommodate a new doctoral program in library and information science and to enhance the existing master's degree program. 